Article

\title{
Structural Study of Mismatched Disila-Crown Ether Complexes
}

\author{
Kirsten Reuter, Fabian Dankert, Carsten Donsbach and Carsten von Hänisch * \\ Fachbereich Chemie and Wissenschaftliches Zentrum für Materialwissenschaften (WZMW), \\ Philipps-Universität Marburg, Hans-Meerwein Straße 4, D-35032 Marburg, Germany; \\ kirsten.reuter@staff.uni-marburg.de (K.R.); Dankert@students.uni-marburg.de (F.D.); \\ donsbach@students.uni-marburg.de (C.D.) \\ * Correspondence: haenisch@chemie.uni-marburg.de; Tel.: +49-0-6421-282-5612
}

Academic Editor: Matthias Westerhausen

Received: 21 December 2016; Accepted: 2 February 2017; Published: 9 February 2017

\begin{abstract}
Mismatched complexes of the alkali metals cations $\mathrm{Li}^{+}$and $\mathrm{Na}^{+}$were synthesized from 1,2-disila[18]crown-6 (1 and $\mathbf{2}$ ) and of $\mathrm{K}^{+}$from 1,2,4,5-tetrasila[18]crown-6 (4). In these alkali metal complexes, not all crown ether $\mathrm{O}$ atoms participate in the coordination, which depicts the coordination ability of the C-, Si/C-, and Si-bonded O atoms. Furthermore, the inverse case-the coordination of the large $\mathrm{Ba}^{2+}$ ion by the relatively small ligand 1,2-disila[15]crown-5-was investigated, yielding the dinuclear complex 5 . This structure represents a first outlook on sandwich complexes based on hybrid crown ethers.
\end{abstract}

Keywords: hybrid crown ether; siloxane; disilane; mismatch complex; host-guest chemistry

\section{Introduction}

The nature of the Si-O bond has been intensively studied over the past six decades. In the 1960s especially, the large valence angle in disiloxanes and the unusual short $\mathrm{Si}-\mathrm{O}$ bond length, e.g., in $\mathrm{O}\left(\mathrm{SiH}_{2} \mathrm{Me}_{2}\right)_{2}$, were issued in numerous publications $[1,2]$. The low basicity of siloxanes was originally attributed to an electron-withdrawing tendency of the silyl groups of the type $\mathrm{p}(\mathrm{O}) \rightarrow \mathrm{d}(\mathrm{Si})$ [3-5]. This approach was later discarded in favor of hyperconjugation interactions between $\mathrm{p}(\mathrm{O}) \rightarrow \sigma^{*}(\mathrm{Si}-\mathrm{C})[6-8]$. Alternatively, in an opposed model based on calculations of the electron density function, the Si-O bond was described as essentially ionic due to the high difference in electronegativity between $\mathrm{Si}$ and $\mathrm{O}[9,10]$. Careful theoretical studies on the basicity of $\mathrm{O}\left(\mathrm{SiH}_{2} \mathrm{Me}_{2}\right)_{2}$ and $\mathrm{OEt}_{2}$ revealed that the lower electrostatic attraction in siloxanes results from the repulsion between the positively charged $\mathrm{Si}$ atoms and Lewis acids [11]. This proceeding has recently been extended on cyclosiloxanes [12], which were previously described as pseudo crown ethers or inorganic crown ethers [13-15]. However, the structural analogy to organic crown ethers is poor, since siloxanes feature $\mathrm{O}$ atoms linked by $-\mathrm{SiMe}_{2}-$ rather than $-\mathrm{CH}_{2} \mathrm{CH}_{2}-$. Additionally, organic ring-contracted crown ethers exhibit an eminently reduced coordination ability, as has been shown in the referencing of [17]crown-6, in which only one $-\mathrm{CH}_{2} \mathrm{CH}_{2}$ - unit was replaced by $-\mathrm{CH}_{2}-[16,17]$. Consequently, higher comparability between organic crown ethers and cyclosiloxanes can be provided by extension of the - $-\mathrm{SiMe}_{2}-$ unit to $-\mathrm{SiMe}_{2} \mathrm{SiMe}_{2}-$. Recent studies of hybrid [12]crown-4 featuring one or two disilane fragments in a residuary organic crown ether framework revealed an increasing coordination ability towards $\mathrm{Li}^{+}$in the series $\mathrm{C}-\mathrm{O}-\mathrm{C}<$ $\mathrm{C}-\mathrm{O}-\mathrm{Si}<\mathrm{Si}-\mathrm{O}-\mathrm{Si}$ (Scheme 1) $[18,19]$.

Another deviation between the hitherto discussed cyclosiloxanes and organic crown ethers concerns the substituents at $\mathrm{Si}$ and $\mathrm{C}$. Up to date, neither cyclosiloxanes with H-substituents at the $\mathrm{Si}$ atoms nor permethylated crown ethers have been synthesized, which complicates a meaningful comparison of the two types of ligands. Calculation of the energy changes for crown 
ethers, cyclosiloxanes and hybrid crown ethers going from the free ligand geometries to complex geometries-determined as relaxation energy-revealed that $\mathrm{SiMe}_{2}$ or $\mathrm{Si}_{2} \mathrm{Me}_{4}$ containing ligands require steadily more energy for adopting the complex geometry $[12,18,19]$. The complex stability is directly affected by the relaxation energy, which is in the case of the hybrid crown ethers compensated by the particularly high donor ability of the $\mathrm{O}$ atoms [18].

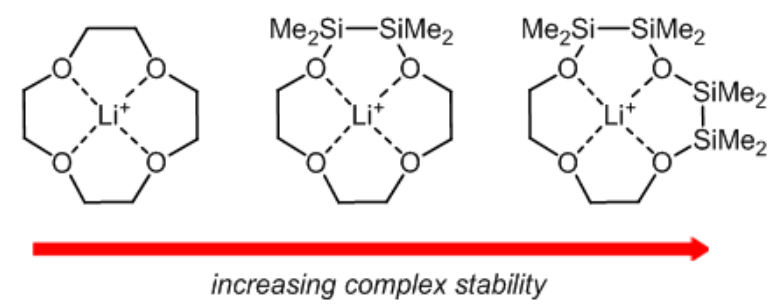

Scheme 1. Binding modes and relative binding affinities of $\mathrm{Li}^{+}$in [12]crown-4, 1,2-disila[12]crown-4, and 1,2,4,5-tetrasila[12]crown-4.

The hitherto described hybrid crown ethers exhibit up to three different types of $\mathrm{O}$ atoms-all C-, C/Si-, and all Si-bonded ones (Scheme 1). To experimentally explore the competition between the basicity of the inequivalent $\mathrm{O}$ atoms and the energy effort for reaching the ligand geometry in the complex, we performed complexation reactions using small alkali and alkaline earth metal ions and comparatively large ligands. As a result, the ligand exceeds with its ring diameter the ionic radius of the Lewis acid. Since particularly Si-based crown ethers show limited flexibility [11-15,18,19], we expected not all $\mathrm{O}_{\text {crown }}$ atoms to participate in the coordination of the metal center [20-22]. The first mismatch structure of a hybrid crown ether was very recently published and is constituted of 1,2-disila[18]crown- 6 and $\mathrm{Ca}(\mathrm{OTf})_{2}\left(\mathrm{OTf}={ }^{-} \mathrm{OSO}_{2} \mathrm{CF}_{3}\right)$ [23]. Therein, one of the $\mathrm{C}$-bonded $\mathrm{O}$ atoms does not participate in the coordination of $\mathrm{Ca}^{2+}$, showing the preference of the metal ion to be coordinated by the $\mathrm{Si} / \mathrm{C}$-linked $\mathrm{O}$ atoms. This preference depicts the coordination ability of the $\mathrm{O}$ atoms in partially Si-based crown ethers and is a matter of investigation in this work.

\section{Results and Discussion}

\subsection{Mismatch Complexes Involving 1,2-Disila[18]crown-6 with $\mathrm{Li}^{+}$and $\mathrm{Na}^{+}$}

The hybrid ligand 1,2-disila[18]crown-6 was synthesized in a single step reaction from 1,2-dichlorodisilane and pentaethylene glycol (Scheme 2). Prior studies have shown that $\mathrm{Li}^{+}$matches well with 1,2-disila[12]crown-4 and $\mathrm{Na}^{+}$with 1,2-disila[15]crown-5 [18], so that the two cations together with 1,2-disila[18]crown-6 are supposed to fulfil the criteria of a mismatch. Reaction of 1,2-disila[18]crown-6 with lithium hexafluorophosphat in a 1:1 stoichiometry yielded a highly viscous oil. After freezing at $-196{ }^{\circ} \mathrm{C}$ and subsequent storage at $-35^{\circ} \mathrm{C}$ for 3 days, Compound $\mathbf{1}$ crystallized in the space group $P 2_{1} / c$ in the form of colorless planks. In the solid-state structure of Compound $\mathbf{1}$, $\mathrm{Li}^{+}$is coordinated by five of the six crown ether $\mathrm{O}$ atoms (Figure 1). The non-coordinating completely carbon-bonded $\mathrm{O}$ atom $\mathrm{O} 5$ shows an atomic distance of 295.7(5) pm to the $\mathrm{Li}^{+}$cation. The $\mathrm{PF}_{6}$ anion does not interact with the cation. The coordination polyhedron can be described as a distorted trigonal bipyramid (Figure 2). The three equatorial $\mathrm{O}$ atoms $(\mathrm{O} 2, \mathrm{O} 4, \mathrm{O} 6)$ establish shorter bond lengths to the cation than the two axial $\mathrm{O}$ atoms. The shortest $\mathrm{Li}-\mathrm{O}$ bond length has a value of 194.9(5) pm (Li1-O6), while the longest bond length measures 224.8(5) pm (Li1-O1). Compared to the hitherto known lithium complexes of hybrid sila-crown ethers, the Li1-O1 bond length is elongated, which may be the result of the strongly twisted ligand. Typically, the $\mathrm{O}$ atoms in sila-crown ethers complexes adopt an approximately planar conformation [13-15,18,19]. The disilane fragment in $\mathbf{1}$ is roughly coplanar to the thereon bonded $\mathrm{O}$ atoms $\mathrm{O} 1$ and $\mathrm{O} 2$, but the organic part of the ligand is strongly twisted and is wrapped around the metal center. 


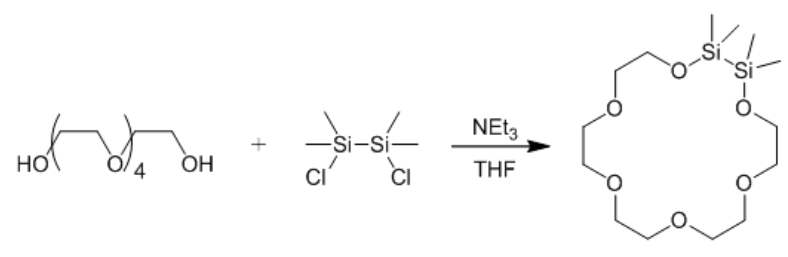

Scheme 2. Synthesis path for 1,2-disila[18]crown-6 [18].

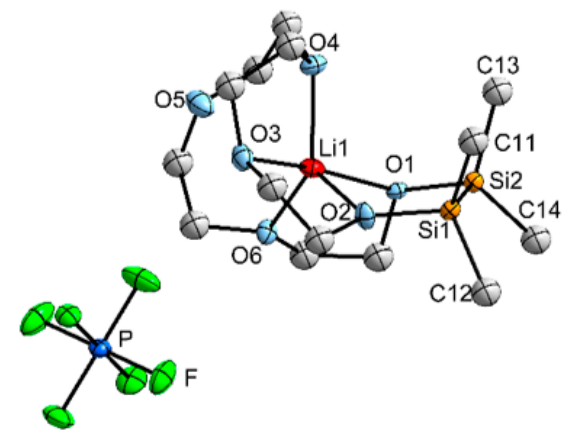

Figure 1. Molecular structure of [Li(1,2-disila[18]crown-6)]PF 6 (1) in the crystal. Thermal ellipsoids represent the $50 \%$ probability level. Hydrogen atoms are omitted for clarity. Selected bond lengths (pm) and angles $\left(^{\circ}\right)$ : Si1-Si2: 235.1(1), Si1-O1: 168.9(2), Si2-O2: 167.9(2), Li1-O1: 224.8(5), Li1-O2: 200.4(5), Li1-O3: 212.1(5), Li1‥O5: 295.7(5), Li1-O6: 194.9(5), O3-Li1-O1: 169.4(2), O2-Li1-O4: 115.9(2), O2-Li1-O6: 111.6(2), O4-Li1-O6: 132.5(2), O1-Li1-O4: 102.3(2), O1-Li1-O2: 88.9(2), O1-Li1-O6: 79.5(2), C11-Si2-Si1-C13: 9.6(1), C12-Si2-Si1-C14: 8.9(1).

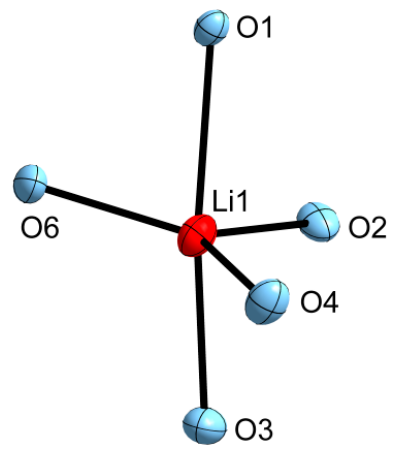

Figure 2. Trigonal bipyramidal coordination polyhedron of the lithium cation in [Li(1,2-disila[18]crown-6)]PF 6 (1).

Trigonal bipyramidal coordination is common for mismatched crown ether complexes of lithium [24,25], while in [12]crown-4 complexes the square-pyramid [26,27] or in sandwich complexes the square antiprism is the usual coordination polyhedron [28]. In prior studies on sila-crown ether complexes, it was already shown that the Me groups at the $\mathrm{Si}$ atoms take in a roughly eclipsed conformation $[18,19,23]$. In $\mathbf{1}$, the Me groups adopt with dihedral angles of 9.6(1) ${ }^{\circ}$ for C11-Si2-Si1-C13, and $8.9(1)^{\circ}$ for $\mathrm{C} 12-\mathrm{Si} 2-\mathrm{Si} 1-\mathrm{C} 14$ the expected conformation of the complex. As a result, the attractive electrostatic interaction between the $\mathrm{Si} / \mathrm{C}$-bonded $\mathrm{O}$ atoms and the $\mathrm{Li}^{+}$cation must compensate for the required energy effort of the ecliptic arrangement. The ${ }^{29} \mathrm{Si}\left\{{ }^{1} \mathrm{H}\right\}$-NMR signal shifts from $\delta=11.4 \mathrm{ppm}$ in the free ligand to $\delta=15.6 \mathrm{ppm}$ in $\mathbf{1}$, indicating a strong electrostatic interaction between $\mathrm{Li}^{+}$ and $\mathrm{O} 1$ and $\mathrm{O} 2$. The strong shift also reflects the hard Lewis acidity in comparison to $\mathrm{K}^{+}$, since in [K(1,2-disila[18]crown-6) $\mathrm{PF}_{6}$ ] the respective ${ }^{29} \mathrm{Si}\left\{{ }^{1} \mathrm{H}\right\}$-NMR signal is at $\delta=13.0 \mathrm{ppm}$ [18].

By an analogous reaction of $\mathrm{NaPF}_{6}$ with 1,2-disila[18]crown-6, single crystals in form of colorless blocks were obtained from dichloromethane/benzene (2:1). [Na(1,2-disila[18]crown-6) $\left.\mathrm{PF}_{6}\right]$ (2) crystallizes in the triclinic space group $P \overline{1}$ as a monomeric contact ion pair (Figure 3). $\mathrm{Na}^{+}$is 
coordinated by five of the six crown ether $\mathrm{O}$ atoms and additionally by two $\mathrm{F}$ atoms of the $\mathrm{PF}_{6}$ anion. The coordination sphere of $\mathrm{Na}^{+}$cannot be assigned to a hitherto described polyhedron as a result of its strong distortion. Compared to $\mathrm{K}^{+}$, the ionic radius of $\mathrm{Na}^{+}$is still too small for the cavity diameter of 1,2-disila[18]crown-6. As a result, $\mathrm{O} 1$ is with a distance of 453.2(3) pm not participating in the coordination of the metal ion. This leads to a strong distortion of the ring system, as $\mathrm{O} 1$ is located significantly beneath the mean plane of the other crown ether $\mathrm{O}$ atoms. Additionally, the Me groups at the Si atoms show a staggered arrangement, which is the common structure in free hybrid crown ethers [18]. In the case of Compound 2, the electrostatic attraction between $\mathrm{O} 1$ and $\mathrm{Na}^{+}$apparently does not compensate for the adoption of an ecliptic arrangement, so the cation is preferably coordinated by the C-bonded $\mathrm{O}$ atoms. The coordinating $\mathrm{Si}$ - and $\mathrm{C}$-linked $\mathrm{O}$ atom $\mathrm{O} 2$ establishes a bond length of 238.5(3) pm to the metal, while the completely C-linked $\mathrm{O}$ atoms show values between $237.0(3)$ and 247.3(2) pm. The ${ }^{29} \mathrm{Si}\left\{{ }^{1} \mathrm{H}\right\}-\mathrm{NMR}$ signal of Compound 2 appears at $\delta=14.3 \mathrm{ppm}$ and, according to the respective Lewis acidity of $\mathrm{Li}^{+}$and $\mathrm{Na}^{+}$, is less low-field shifted compared to 1 .

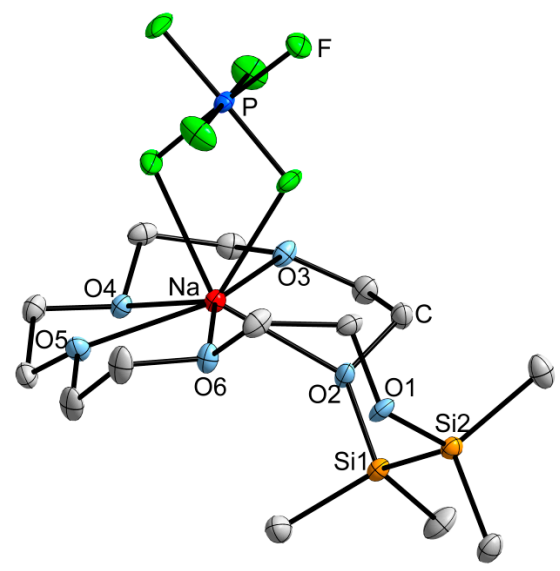

Figure 3. Molecular structure of $\left[\mathrm{Na}\left(1,2-\right.\right.$ disila[18]crown-6) $\left.\mathrm{PF}_{6}\right](2)$ in the crystal. Thermal ellipsoids represent the $50 \%$ probability level. Hydrogen atoms are not displayed. Selected bond lengths

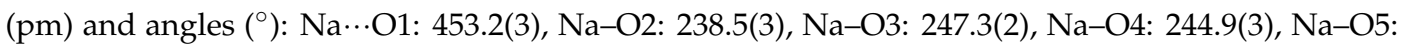
237.0(3), Si1-Si2: 235.8(1), Si2-O1: 166.2(3), Si1-O2: 167.5(2), Si2-O1-C10: 122.7(2), Si1-O2-C1: 121.7(2), C4-O4-C5: 113.5(2), C13-Si1-Si2-C11: 66.0(2), C14-Si1-Si2-C12: 65.6(2).

\subsection{Determination of $\Delta E_{\text {geom }}$ in 1,2-Disila[18]crown-6 Complexes}

As was shown in prior studies, hybrid crown ethers require steadily more energy than organic crown ethers for adopting the ligand structure within the complex $[18,19,23]$. The increase in relaxation energy was partially attributed to the sterically disfavored ecliptic arrangement of the Me groups bonded at the Si atoms. That was found to be the predominant conformation in the hybrid crown ether complex structures. The mismatched complexes $\mathbf{1}$ and $\mathbf{2}$ offer two different coordination modes of the $\mathrm{Si} / \mathrm{C}$-bonded $\mathrm{O}$ atoms: In the case of the Li-complex 1, both Si-bonded $\mathrm{O}$ atoms participate in the coordination, while in the Na-complex 2, only one of the Si/C-bonded O atoms binds to the metal center, which results in a staggered arrangement of the Me groups. It follows that 1,2-disila[18]crown-6 is expected to exhibit considerable different energy levels in the complex structures 1 and 2 . The energy difference $\Delta E_{\text {geom }}$ was determined by DFT calculations, implemented in Turbomole V7.0 [28], using the BP86 functional [29-32] and the def2-TZVP basis set with inclusion of dispersion interactions [33,34]. Accordingly, the energy of the ligand increases by $77.58 \mathrm{~kJ} \cdot \mathrm{mol}^{-1}$ for adopting the structure found within [Li(1,2-disila[18]crown-6)] ${ }^{+}$and by $29.24 \mathrm{~kJ} \cdot \mathrm{mol}^{-1}$ for $^{-}$ $\left[\mathrm{Na}(1,2-\text { disila[18]crown-6) }]^{+}\right.$. The electrostatic attraction between the Si/C-bonded $\mathrm{O}$ atoms and $\mathrm{Na}^{+}$does not compensate for the ecliptic conformation of the Me groups. By contrast, $\mathrm{Li}^{+}$must exhibit a significantly increased electrostatic attraction to the hybrid-bonded $\mathrm{O}$ atoms. The mismatched 
hybrid crown ether complexes $\mathbf{1}$ and $\mathbf{2}$ therefore suggest that the cation exerts a major impact on the coordination modes of the ligand.

The optimized structure of the free ligand 1,2-disila[18]crown-6 shows, as expected, a staggered conformation of the methyl groups at the silicon atoms. The DFT calculated structures of the cations in Compounds $\mathbf{1}$ and $\mathbf{2}$ exhibit only very small differences in the structural parameter in comparison to the structures obtained by X-ray diffraction (see XYZ data in the ESI).

\subsection{Mismatch Involving 1,2,4,5-Tetrasila[18]crown-6 and $\mathrm{K}^{+}$}

The synthesis of hybrid crown ethers with a higher amount of disilane units was very recently described for 1,2,4,5-tetrasila[12]crown-4 [19]. In an analogous reaction of $\mathrm{O}\left(\mathrm{Si}_{2} \mathrm{Me}_{4} \mathrm{Cl}\right)_{2}$ with tetraethylene glycol, the ligand 1,2,4,5-tetrasila[18]crown-6 (3) was synthesized using high dilution of the agents to prevent polymerization (Scheme 3). Compound 3 is a highly viscous, colorless oil. Through the presence of two disilane units, the ring size is further increased in comparison to 1,2-disila[18]crown-6. In the ${ }^{29} \mathrm{Si}\left\{{ }^{1} \mathrm{H}\right\}$-NMR spectrum, Compound 3 shows two signals which can be assigned to the two types of $\mathrm{Si}$ atoms: The $\mathrm{Si}-\mathrm{O}-\mathrm{Si}$ entity appears at $\delta=2.1 \mathrm{ppm}$, the $\mathrm{C}-\mathrm{O}-\mathrm{Si}$ entity is low-field shifted and appears at $\delta=11.0 \mathrm{ppm}$.

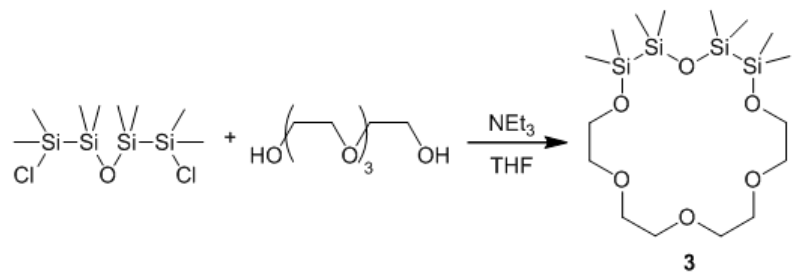

Scheme 3. Synthesis path of 1,2,4,5-tetrasila[18]crown-6 (3).

Treatment of 3 with $\mathrm{KPF}_{6}$ yielded the corresponding, highly water sensitive complex [K(1,2,4,5-tetrasila[18]crown-6) $\left.\mathrm{PF}_{6}\right]$ (4). Different to the hitherto known hybrid disila-crown ether complexes, 4 is directly after removal of the volatiles an oily compound, which crystallizes within $18 \mathrm{~h}$ at ambient temperature in form of colorless planks in the space group $P 2_{1} / n$.

As observed in the $\mathrm{Na}^{+}$complex 2, Compound 4 is a monomeric contact ion pair (Figure 4). The cation is coordinated by five of the six crown ether $\mathrm{O}$ atoms and three $\mathrm{F}$ atoms of the anion, giving a coordination number of eight. The incorporation of two disilane units into the ring system leads to an increased ring diameter so that $\mathrm{K}^{+}$, which commonly matches perfectly with [18]crown-6, has a too small ionic radius for the ligand 3 . The inorganic part sticks out, showing an interatomic distance of 505.5(2) pm between the completely Si substituted O atom O2 and the metal ion. The Me groups at the $\mathrm{Si}$ atoms adopt an approximately staggered conformation with average dihedral angles of $84.2(2)^{\circ}$ at $\mathrm{Si} 1 / \mathrm{Si} 2$ and $59.8(2)^{\circ}$ at $\mathrm{Si3} / \mathrm{Si} 4$. Worth mentioning is the unusual orientation of Si4: In all hitherto known sila-crown ether complexes, the $\mathrm{Si}$ atoms bonded to coordinating $\mathrm{O}$ atoms are approximately arranged in plane with the crown ether $O$ atoms $[12-15,18,19,23]$. In contrast to this, Si4 is considerably located beneath the mean plane of the coordinating $\mathrm{O}$ atoms. The $\mathrm{Si} / \mathrm{C}$-bonded $\mathrm{O}$ atoms $\mathrm{O} 1$ and $\mathrm{O} 3$ show O-K bond lengths of 283.8(2) and 279.4(2) pm, whereas the fully C-substituted $\mathrm{O}$ atoms $\mathrm{O} 4-\mathrm{O} 6$ establish average bond lengths of 273.7(2) pm. It can therefore be assumed that $\mathrm{K}^{+}$is stronger coordinated by the carbon-based part of the hybrid crown ether 3 . Compared to $\left[\mathrm{K}\left(1,2-\right.\right.$ disila[18]crown-6) $\left.\mathrm{PF}_{6}\right]$, which incorporates only one disilane unit and in which all crown ether atoms are participating in the coordination, the mean $\mathrm{O}-\mathrm{K}$ bond lengths are in 4 considerably shorter [18]. This can be related to the coordination number of 8 in 4 compared to 9 in $\left[\mathrm{K}\left(1,2\right.\right.$-disila[18]crown-6) $\left.\mathrm{PF}_{6}\right]$. The Si2-O2-Si3 bond angle is $143.8(1)^{\circ}$, this is a typical value for siloxanes $[1,2]$. Also the Si4-O3-C9 bond angle of $123.3(2)^{\circ}$ is in the expected range $[18,19]$. Only the Si1-O1-C16 angle is with $117.8(1)^{\circ}$ smaller than usually observed and is similar to that found in C-O-C bindings, e.g., C14-O6-C15 with 112.3(2) ${ }^{\circ}$. 


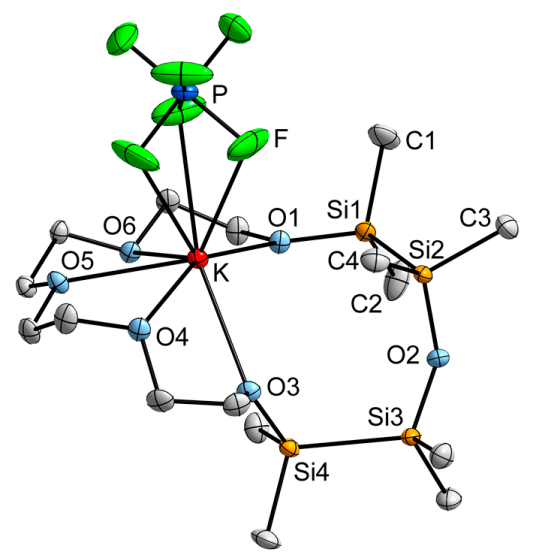

Figure 4. Molecular structure of $\left[\mathrm{K}\left(1,2,4,5\right.\right.$-tetrasila[18]crown-6) $\left.\mathrm{PF}_{6}\right](4)$ in the crystal. Thermal ellipsoids represent the $50 \%$ probability level. Hydrogen atoms are not displayed. Selected bond

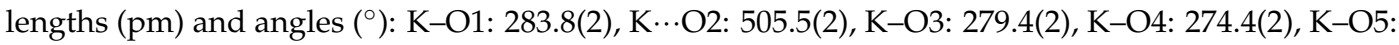
272.3(2), K-O6: 274.3(2), Si1-Si2: 234.9(1), Si1-O1: 166.5(2), Si2-O2: 164.5(2), Si3-O2: 165.2(2), Si4-O3: 166.7(2); Si4-O3-C9: 123.3(2), Si2-O2-Si3: 143.8(1), Si1-O1-C16: 117.8(1), C14-O6-C15: 112.3(2), C1-Si1-Si2-C4: 84.1(2), C2-Si1-Si2-C3: 84.2(1), C6-Si3-Si4-C8: 59.5(1), C5-Si3-Si4-C7: 60.1(1).

The reluctance of $\mathrm{K}^{+}$to interact with the Si-substituted $\mathrm{O}$ atoms was also observed in solution and can be deducted from the shifts in the ${ }^{29} \mathrm{Si}\left\{{ }^{1} \mathrm{H}\right\}-\mathrm{NMR}$ spectrum: The resonance signal of $\mathrm{Si} 2 / \mathrm{Si} 3$ shows only a slight low-field shift to $\delta=2.7 \mathrm{ppm}(\Delta(\delta)=0.6 \mathrm{ppm})$ and the signal of Si1/Si4 appears at $\delta=11.9 \mathrm{ppm}(\Delta(\delta)=0.9 \mathrm{ppm})$. In comparison, the ${ }^{29} \mathrm{Si}\left\{{ }^{1} \mathrm{H}\right\}$-NMR signals of $1,2-$ disila[18]crown-6 shift from $\delta=11.4 \mathrm{ppm}$ in the free ligand to $\delta=13.0 \mathrm{ppm}$ in the potassium complex [18]. The small shift of the ${ }^{29} \mathrm{Si}\left\{{ }^{1} \mathrm{H}\right\}$ signal indicates that also in solution $\mathrm{O} 2$ shows only minor interaction with the $\mathrm{K}^{+}$ion, owing to the high energy effort of $\mathrm{Si}_{2} \mathrm{Me}_{4}$ fragments to adopt the ecliptic geometry.

\subsection{The Inverse Case: 1,2-Disila[15]crown-5 and $\mathrm{Ba}^{2+}$}

Beside experiments involving large ligands with comparatively small cations, we also investigated the inverse mismatch case, i.e., 1,2-disila[15]crown-5 with $\mathrm{BaOTf}_{2}\left(\mathrm{OTf}={ }^{-} \mathrm{OSO}_{2} \mathrm{CF}_{3}\right)$. Prior studies revealed that $\mathrm{Ba}^{2+}$ perfectly matches with 1,2-disila[18]crown-6 and 1,2-disila-benzo[18]crown-6. In the corresponding complex, $\mathrm{Ba}^{2+}$ is located in one plane with the coordinating $\mathrm{O}$ atoms and is saturated by two triflate groups, which are arranged upon and beneath the crown ether mean plane [23]. Reaction of 1,2-disila[15]crown-5 with $\mathrm{BaOTf}_{2}$ in 1:1 stoichiometry yielded colorless blocks of $\left[\mathrm{Ba}(1,2-\mathrm{disila}[15] \mathrm{crown}-5) \mathrm{OTf}_{2}\right]_{2}(5)$ in the triclinic space group $P \overline{1}$. Different to the hitherto known sila-crown ether complexes, 5 forms a dinuclear complex (Figure 5). The four triflate anions act as bridges between the two metal centers and participate in the saturation of the coordination sphere with four $\mathrm{O}$ atoms, respectively. Furthermore, $\mathrm{Ba}^{2+}$ is coordinated by the five crown ether $\mathrm{O}$ atoms, giving a coordination number of 9 . The ion $\mathrm{Ba}(1)$ is located 156.8(2) pm above the calculated mean plane of the $\mathrm{O}_{\text {crown }}$ atoms, which reflects the small ring diameter of 1,2-disila[15]crown-5 compared to the ionic radius of $\mathrm{Ba}^{2+}$. The disilane units of the crown ethers show in opposite directions to each other as a result of the sterically demanding methyl groups. The typical approximately ecliptic arrangement of the methyl groups in sila-crown ethers complexes can also be found in Compound 5 . However, the dihedral angles have values of $26.1(3)^{\circ}$ and $22.8(3)^{\circ}$ and accordingly show stronger deviations from the ideal ecliptic arrangement compared to those found in other hybrid-crown ether complexes. The Si/C-bonded O atoms O1 and O5 establish bond lengths of 283.4(1) and 286.5(1) pm to the cation and are in a similar range with C-bonded $\mathrm{O}$ atoms, which show $\mathrm{O}-\mathrm{Ba}$ bonds between 280.4(1) and $287.7(1) \mathrm{pm}$. $\mathrm{Ba}^{2+}$ is furthermore strongly coordinated by the triflate $\mathrm{O}$ atoms since the bonding to $\mathrm{Ba}(1)$ has an average value of $275.7(4) \mathrm{pm}$. Another indication for the weak coordination of $\mathrm{Ba}^{2+}$ by 
1,2-disila[15]crown-5 was revealed by mass spectrometric analysis: Only [ $\mathrm{Na}\left(1,2\right.$-disila[15]crown-5) ${ }^{+}$ was detected. $\mathrm{Na}^{+}$is a common impurity in mass spectrometers, so $\mathrm{Ba}^{2+}$ was immediately replaced.

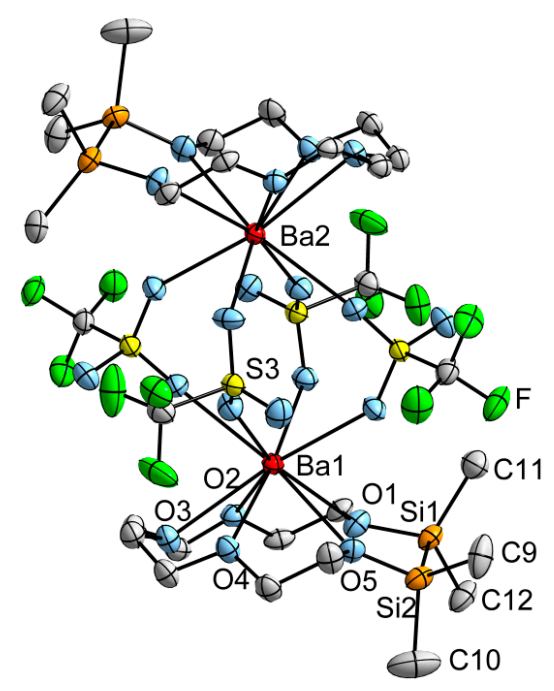

Figure 5. Molecular structure of $\left[\mathrm{Ba}(1,2 \mathrm{disila}[15] \text { crown-5)OTf } 2]_{2}\right.$ (5) in the crystal. Thermal ellipsoids represent the $50 \%$ probability level. Hydrogen atoms are not displayed. Selected bond lengths (pm) and angles $\left({ }^{\circ}\right)$ : Ba1-O1: 283.4(1), Ba1-O2: 287.7(1), Ba1-O3: 280.4(1), Ba1-O4: 287.7(4), Ba1-O5: 286.5(1), Ba1-OOTf: 269.4(1)-278.7(1), Si1-Si2: 234.6(2), Si1-O1: 167.2(4), 165.9(3), Ba1B.B2: 527.1(2), Si1-O1-C1: 121.5(3), Si2-O5-C8: 121.6(3), C4-O3-C5: 114.9(4), C11-Si1-Si2-C9: 26.1(3), C12-Si1-Si2-C10: 22.8(3).

\section{Materials and Methods}

\subsection{General Experimental Technique}

All working procedures were conducted under exclusion of oxygen and moisture using Schlenk techniques under a nitrogen atmosphere. Solvents were dried and freshly distilled before use. Nuclear magnetic resonance (NMR) spectra were recorded with BRUKER Model AVANCE HD300, BRUKER Model DRX400, or BRUKER Model AVANCE500 spectrometers (Bruker Corporation, Rheinstetten, Germany) and were visualized with MestReNova [35]. Infrared (IR) spectra were recorded in attenuated total reflectance (ATR) mode on a BRUKER model ALPHA FT-IR. MS spectrometry was measured on a LTQ-FT (ESI, Thermo Fischer Scientific, Darmstadt, Germany) or on a JEOL AccuTOF-GC (LIFDI, JEOL, Freising, Germany). Elemental analysis data cannot be provided due to the presence of fluorine in the samples, which harm the elemental analysis devices. The ligands 1,2-disila[18]crown-6 and 1,2-disila[15]crown-5 [18] and $\mathrm{O}\left(\mathrm{Si}_{2} \mathrm{Me}_{4} \mathrm{Cl}\right)_{2}$ [19] were prepared by reported methods.

\subsection{Computational Details}

Calculations were performed with Turbomole V7.0 [28]. The resolution of identity (RI) approximation, dispersion corrections [29-32], and the conductor-like screening (COSMO) model [36] were applied, the latter with default settings. For all calculations the BP86 functional and def2-TZVP basis set $[33,34]$ were chosen.

\subsection{Crystal Structures}

Data collection was performed on a Bruker D8 Quest or a Stoe IPDS II diffractometer at 100(2) $\mathrm{K}$ with Mo K $\alpha$ radiation and graphite monochromatization. Structure solution was done by direct methods, refinement with full-matrix-least-squares against $F^{2}$ using shelxs-2014, shelxl-2014, shelxt-2014, and olex2 software (Table 1) [37,38]. The presentation of crystal structures was done 
with Diamond4.2.2 [39]. CCDC 1517535 (1), 1517536 (2), 1517537 (4), and 1517538 (5) contain the supplementary crystallographic data for this paper. These data can be obtained free of charge from The Cambridge Crystallographic Data Centre via www.ccdc.cam.ac.uk/data_request/cif.

Table 1. Crystal Structure Data.

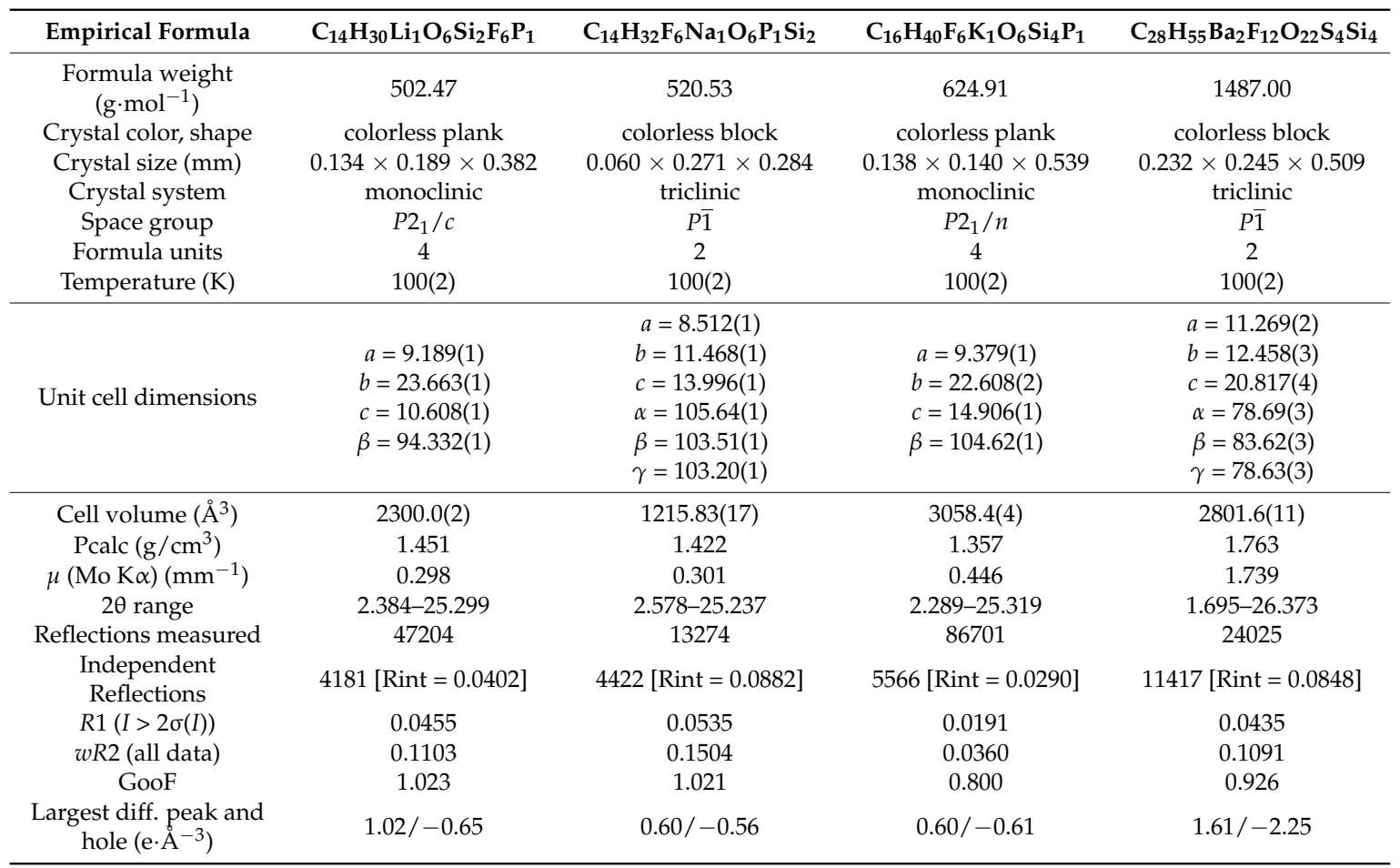

\subsection{Experimental Section}

$\mathrm{Li}\left(1,2\right.$-disila[18]crown-6)] $\mathrm{PF}_{6}$ (1): At ambient temperature, $159 \mathrm{mg}$ (1.05 mmol, 1 equiv) of $\mathrm{LiPF}_{6}$ was added to $370 \mathrm{mg}$ (1.1 mmol, 1 equiv) of 1,2-disila[18]crown-6 in $15 \mathrm{~mL}$ of dichloromethane. The suspension was stirred for $18 \mathrm{~h}$ and was subsequently filtered. The solvent was removed under reduced pressure, and the residue was washed with $n$-pentane. The resulting colorless greasy solid was recrystallized with traces of dichloromethane after freezing at $-196^{\circ} \mathrm{C}$ and subsequently storage at $-35{ }^{\circ} \mathrm{C}$ for 3 days. $45 \%$ ( $\left.275 \mathrm{mg}, 0.5 \mathrm{mmol}\right)$ of 1 was obtained in form of colorless planks. ${ }^{1} \mathrm{H}$ NMR $\left(300 \mathrm{MHz}, \mathrm{CD}_{2} \mathrm{Cl}_{2}\right): \delta=0.34\left(\mathrm{~s}, 12 \mathrm{H}, \mathrm{CH}_{3}\right), 3.71-3.73\left(\mathrm{~m}, 4 \mathrm{H}, \mathrm{CH}_{2}\right), 3.76\left(\mathrm{~s}, 12 \mathrm{H}, \mathrm{CH}_{2}\right), 3.81-3.82 \mathrm{ppm}$ $\left(\mathrm{m}, 4 \mathrm{H}, \mathrm{CH}_{2}\right) ;{ }^{13} \mathrm{C}\left\{{ }^{1} \mathrm{H}\right\} \mathrm{NMR}\left(75 \mathrm{MHz}, \mathrm{CD}_{2} \mathrm{Cl}_{2}\right): \delta=-0.5\left(\mathrm{~s}, \mathrm{CH}_{3}\right), 61.7\left(\mathrm{~s}, \mathrm{CH}_{2}\right), 68.1\left(\mathrm{~s}, \mathrm{CH}_{2}\right), 68.2(\mathrm{~s}$, $\left.\mathrm{CH}_{2}\right), 68.4\left(\mathrm{~s}, \mathrm{CH}_{2}\right), 71.4 \mathrm{ppm}\left(\mathrm{s}, \mathrm{CH}_{2}\right) ;{ }^{29} \mathrm{Si}\left\{{ }^{1} \mathrm{H}\right\} \mathrm{NMR}\left(\mathrm{CD}_{2} \mathrm{Cl}_{2}\right): \delta=15.6 \mathrm{ppm}(\mathrm{s}) ;{ }^{7} \mathrm{Li} \mathrm{NMR}(194 \mathrm{MHz}$, $\left.\mathrm{CD}_{2} \mathrm{Cl}_{2}\right): \delta=-0.9 \mathrm{ppm}(\mathrm{s}) ;{ }^{31} \mathrm{P}\left\{{ }^{1} \mathrm{H}\right\} \mathrm{NMR}\left(117 \mathrm{MHz}, \mathrm{CD}_{2} \mathrm{Cl}_{2}\right): \delta=-144.0 \mathrm{ppm}\left(\mathrm{h},{ }^{1} J_{\mathrm{PF}}=710 \mathrm{~Hz}\right)$; ${ }^{19} \mathrm{~F} \mathrm{NMR}\left(283 \mathrm{MHz}, \mathrm{CD}_{2} \mathrm{Cl}_{2}\right): \delta=-73.7 \mathrm{ppm}\left(\mathrm{d},{ }^{1} J_{\mathrm{PF}}=710 \mathrm{~Hz}\right)$. IR $\tilde{v}=2962(\mathrm{w}), 2885(\mathrm{vw}), 1456(\mathrm{vw})$, 1410(vw), 1351(vw), 1258(m), 1057(s), 1011(s), 923(w), 789(vs), 701(w), 661(w), 635(w), 556(m), 466(m). MS (ESI $\left.{ }^{+}\right): m / z 359.1893 \%[M]^{+}-\mathrm{PF}_{6}(95)$.

[Na(1,2-disila[18]crown-6) $\mathrm{PF}_{6}$ ] (2): At ambient temperature, $48 \mathrm{mg}$ ( $0.3 \mathrm{mmol}, 1$ equiv) of $\mathrm{NaPF}_{6}$ was added to $100 \mathrm{mg}(0.28 \mathrm{mmol}, 1$ equiv) of 1,2-disila[18]crown- 6 in $10 \mathrm{~mL}$ of dichloromethane. The suspension was stirred for $1 \mathrm{~h}$, followed by filtration and removal of the solvent. The residue was washed twice with $10 \mathrm{~mL}$ of $n$-pentane and was dried in vacuo. Recrystallization from dichloromethane: benzene (2:1) at $-35{ }^{\circ} \mathrm{C}$ yielded $44 \%(64 \mathrm{mg}, 0.12 \mathrm{mmol})$ of 2 in form of colorless blocks after 1 day. ${ }^{1} \mathrm{H}$ NMR $\left(300 \mathrm{MHz}, \mathrm{CD}_{2} \mathrm{Cl}_{2}\right): \delta=0.29\left(\mathrm{~s}, 12 \mathrm{H}, \mathrm{CH}_{3}\right), 3.61-3.63\left(\mathrm{~m}, 4 \mathrm{H}, \mathrm{CH}_{2}\right), 3.67\left(\mathrm{~s}, 12 \mathrm{H}, \mathrm{CH}_{2}\right)$, 3.80-3.83 ppm (m, 4H, CH $) ;{ }^{13} \mathrm{C}\left\{{ }^{1} \mathrm{H}\right\} \operatorname{NMR}\left(75 \mathrm{MHz}, \mathrm{CD}_{2} \mathrm{Cl}_{2}\right): \delta=-0.4\left(\mathrm{~s}, \mathrm{CH}_{3}\right), 62.8\left(\mathrm{~s}, \mathrm{CH}_{2}\right), 69.9$ (s, $\left.\mathrm{CH}_{2}\right), 72.0\left(\mathrm{~s}, \mathrm{CH}_{2}\right), 72.9 \mathrm{ppm}\left(\mathrm{s}, \mathrm{CH}_{2}\right) ;{ }^{29} \mathrm{Si}\left\{{ }^{1} \mathrm{H}\right\} \mathrm{NMR}\left(\mathrm{CD}_{2} \mathrm{Cl}_{2}\right): \delta=14.3 \mathrm{ppm}(\mathrm{s}) ;{ }^{31} \mathrm{P}\left\{{ }^{1} \mathrm{H}\right\} \mathrm{NMR}$ $\left(117 \mathrm{MHz}, \mathrm{CD}_{2} \mathrm{Cl}_{2}\right): \delta=-143.9 \mathrm{ppm}\left(\mathrm{h},{ }^{1} J_{\mathrm{PF}}=710 \mathrm{~Hz}\right) ;{ }^{19} \mathrm{~F} \mathrm{NMR}\left(283 \mathrm{MHz}, \mathrm{CD}_{2} \mathrm{Cl}_{2}\right): \delta=-74.8 \mathrm{ppm}$ 
$\left(\mathrm{d},{ }^{1} J_{\mathrm{PF}}=710 \mathrm{~Hz}\right)$. IR $\tilde{v}=2912(\mathrm{w}), 2880(\mathrm{w}), 1457(\mathrm{w}), 1399(\mathrm{w}), 1350(\mathrm{w}), 1291(\mathrm{w}), 1250(\mathrm{~m}), 1131(\mathrm{~s})$, 1082(s), 1056(s), 955(s), 931(m), 834(vs), 816(vs), 794(s), 771(s), 740(m), 720(m), 635(m), 556(s), 504(w), 471(w). MS (ESI $\left.{ }^{+}\right): m / z 375.1634 \%[M]^{+}-\mathrm{PF}_{6}(100)$.

1,2,4,5-Tetrasila[18]crown-6 (3): $0.7 \mathrm{~mL}$ (4.1 mmol, 1 equiv) of tetraethylene glycol and $1.1 \mathrm{~mL}$ (8.2 mmol, 2 equiv) of $\mathrm{NEt}_{3}$ in $50 \mathrm{~mL}$ of THF was simultaneously, with $1.30 \mathrm{~g}$ ( $4.1 \mathrm{mmol}, 1$ equiv) of $\mathrm{O}\left(\mathrm{Si}_{2} \mathrm{Me}_{4} \mathrm{Cl}\right)_{2}$ in $50 \mathrm{~mL}$ of THF, dropped into a three-neck flask with $50 \mathrm{~mL}$ of stirred THF. The resulting white suspension was stirred for $12 \mathrm{~h}$. Subsequently, the solvent was removed under reduced pressure, the product was extracted with $50 \mathrm{~mL}$ of $n$-pentane followed by filtration. The solvent was removed in vacuo, and $85 \%(1.5 \mathrm{~g}, 3.5 \mathrm{mmol})$ of 3 was obtained in form of a colorless oil. ${ }^{1} \mathrm{H}$ NMR $\left(300 \mathrm{MHz}, \mathrm{CD}_{2} \mathrm{Cl}_{2}\right): \delta=0.20\left(\mathrm{~s}, 12 \mathrm{H}, \mathrm{CH}_{3}\right), 0.22\left(\mathrm{~s}, 12 \mathrm{H}, \mathrm{CH}_{3}\right), 3.54-3.56\left(\mathrm{~m}, 4 \mathrm{H}, \mathrm{CH}_{2}\right), 3.60\left(\mathrm{~s}, 8 \mathrm{H}, \mathrm{CH}_{2}\right)$, 3.72-3.76 ppm $\left(\mathrm{m}, 4 \mathrm{H}, \mathrm{CH}_{2}\right) ;{ }^{13} \mathrm{C}\left\{{ }^{1} \mathrm{H}\right\} \mathrm{NMR}\left(75 \mathrm{MHz}, \mathrm{CD}_{2} \mathrm{Cl}_{2}\right): \delta=-0.5\left(\mathrm{~s}, \mathrm{CH}_{3}\right), 2.9\left(\mathrm{~s}, \mathrm{CH}_{3}\right), 63.9(\mathrm{~s}$, $\left.\mathrm{CH}_{2}\right), 71.2\left(\mathrm{~s}, \mathrm{CH}_{2}\right), 71.6\left(\mathrm{~s}, \mathrm{CH}_{2}\right), 73.1\left(\mathrm{~s}, \mathrm{CH}_{2}\right) ;{ }^{29} \mathrm{Si}\left\{{ }^{1} \mathrm{H}\right\} \mathrm{NMR}\left(\mathrm{CD}_{2} \mathrm{Cl}_{2}\right): \delta=2.1$ (s, SiOSi), $11.0 \mathrm{ppm}(\mathrm{s}$, COSi). IR $\tilde{v}=2949(\mathrm{w}), 2867(\mathrm{w}), 1456(\mathrm{w}), 1400(\mathrm{w}), 1350(\mathrm{w}), 1294(\mathrm{w}), 1246(\mathrm{~m}), 1091(\mathrm{~s}), 1031(\mathrm{~s})$, 947(m), 826(m), 797(s), 761(s), 682(m), 660(m), 635(m), 553(w), 546(w). MS (ESI $\left.{ }^{+}\right): m / z ~ 441.1977 \%[M H]^{+}(15)$.

[K(1,2,4,5-tetrasila[18]crown-6) $\left.\mathrm{PF}_{6}\right]$ (4): $58 \mathrm{mg}\left(0.32 \mathrm{mmol}, 1\right.$ equiv) of $\mathrm{KPF}_{6}$ was added to a stirred solution of $140 \mathrm{mg}$ ( $0.32 \mathrm{mmol}, 1$ equiv) of 1,2,4,5-tetrasila[18]crown-6 in $15 \mathrm{~mL}$ of dichloromethane. The resulting suspension was stirred for $12 \mathrm{~h}$ at ambient temperature, followed by filtration. The solvent was removed in vacuo, and the product was obtained in form of a colorless, highly viscous oil. After $18 \mathrm{~h}$ at ambient temperature, colorless blocks were obtained, yielding $61 \%$ ( $120 \mathrm{mg}, 0.2 \mathrm{mmol})$ of $4 .{ }^{1} \mathrm{H}$ NMR $\left(300 \mathrm{MHz}, \mathrm{CD}_{2} \mathrm{Cl}_{2}\right): \delta=0.08\left(\mathrm{~s}, 12 \mathrm{H}, \mathrm{CH}_{3}\right), 0.23\left(\mathrm{~s}, 12 \mathrm{H}, \mathrm{CH}_{3}\right), 3.54-3.57\left(\mathrm{~m}, 4 \mathrm{H}, \mathrm{CH}_{2}\right)$, $3.62\left(\mathrm{~s}, 8 \mathrm{H}, \mathrm{CH}_{2}\right), 3.73-3.77 \mathrm{ppm}\left(\mathrm{m}, 4 \mathrm{H}, \mathrm{CH}_{2}\right) ;{ }^{13} \mathrm{C}\left\{{ }^{1} \mathrm{H}\right\} \mathrm{NMR}\left(75 \mathrm{MHz}, \mathrm{CD}_{2} \mathrm{Cl}_{2}\right): \delta=-0.6\left(\mathrm{~s}, \mathrm{CH}_{3}\right), 2.8$ $\left(\mathrm{s}, \mathrm{CH}_{3}\right), 63.6\left(\mathrm{~s}, \mathrm{CH}_{2}\right), 71.0\left(\mathrm{~s}, \mathrm{CH}_{2}\right), 71.1\left(\mathrm{~s}, \mathrm{CH}_{2}\right), 73.1 \mathrm{ppm}\left(\mathrm{s}, \mathrm{CH}_{2}\right) ;{ }^{29} \mathrm{Si}\left\{{ }^{1} \mathrm{H}\right\} \mathrm{NMR}\left(\mathrm{CD}_{2} \mathrm{Cl}_{2}\right): \delta=2.7$ (s, SiOSi), 11.9 ppm (s, COSi); ${ }^{31} \mathrm{P}\left\{{ }^{1} \mathrm{H}\right\} \mathrm{NMR}\left(117 \mathrm{MHz}, \mathrm{CD}_{2} \mathrm{Cl}_{2}\right): \delta=-143.9 \mathrm{ppm}\left(\mathrm{h},{ }^{1} J_{\mathrm{PF}}=710 \mathrm{~Hz}\right)$; ${ }^{19} \mathrm{~F} \mathrm{NMR}\left(283 \mathrm{MHz}, \mathrm{CD}_{2} \mathrm{Cl}_{2}\right): \delta=-73.8 \mathrm{ppm}\left(\mathrm{d},{ }^{1} J_{\mathrm{PF}}=710 \mathrm{~Hz}\right) . \mathrm{IR} \tilde{v}=2948(\mathrm{w}), 2886(\mathrm{w}), 1470(\mathrm{w})$, 1458(w), 1401(w), 1360(w), 1349(w), 1301(w), 1247(m), 1126(m), 1110(m), 1095(m), 1085(m), 1065(m), 1051(m), 1017(m), 945(m), 931(m), 916(m), 825(vs), 797(vs), 762(vs), 738(m), 719(w), 684(m), 659(m), 555(s), 441(w), 427(w), 414(w). MS (ESI $\left.{ }^{+}\right): m / z$ 479.1531\% $[M]^{+}-\mathrm{PF}_{6}(100)$.

[Ba(1,2-disila[15]crown-5)OTf $]_{2}$ (5): $119 \mathrm{mg}\left(0.27 \mathrm{mmol}, 1\right.$ equiv) of $\mathrm{BaOTf}_{2}$ was added to $84 \mathrm{mg}$ ( $0.27 \mathrm{mmol}, 1$ equiv) of 1,2-disila[15]crown- 5 in $15 \mathrm{~mL}$ of dichloromethane. The suspension was stirred for $18 \mathrm{~h}$ followed by filtration. The solvent was removed under reduced pressure, and the residue was washed twice with $15 \mathrm{~mL}$ of $n$-pentane. The product was recrystallized from dichloromethane and pentane (2:5). After 1 day at ambient temperature, colorless plates of 5 were obtained with $22 \%$ $(87 \mathrm{mg}, 0.06 \mathrm{mmol})$ yield. ${ }^{1} \mathrm{H}$ NMR $\left(300 \mathrm{MHz}, \mathrm{CD}_{2} \mathrm{Cl}_{2}\right): \delta=0.37\left(\mathrm{~s}, 24 \mathrm{H}, \mathrm{CH}_{3}\right), 3.71-4.04 \mathrm{ppm}(\mathrm{m}, 32 \mathrm{H}$, $\left.\mathrm{CH}_{2}\right) ;{ }^{13} \mathrm{C}\left\{{ }^{1} \mathrm{H}\right\}$ NMR $\left(75 \mathrm{MHz}, \mathrm{CD}_{2} \mathrm{Cl}_{2}\right): \delta=-0.8\left(\mathrm{~s}, \mathrm{CH}_{3}\right), 62.0\left(\mathrm{~s}, \mathrm{CH}_{2}\right), 69.0\left(\mathrm{~s}, \mathrm{CH}_{2}\right), 70.3\left(\mathrm{~s}, \mathrm{CH}_{2}\right)$, $72.6\left(\mathrm{~s}, \mathrm{CH}_{2}\right), 120.9 \mathrm{ppm}\left(\mathrm{q},{ }^{1} J_{\mathrm{CF}}=322 \mathrm{~Hz}, \mathrm{CF}_{3}\right) ;{ }^{19} \mathrm{~F} \mathrm{NMR}\left(283 \mathrm{MHz}, \mathrm{CD}_{2} \mathrm{Cl}_{2}\right): \delta=-79.4 \mathrm{ppm}\left(\mathrm{s}, \mathrm{CF}_{3}\right)$; ${ }^{29} \mathrm{Si}\left\{{ }^{1} \mathrm{H}\right\} \mathrm{NMR}\left(\mathrm{CD}_{2} \mathrm{Cl}_{2}\right): \delta=17.8 \mathrm{ppm}(\mathrm{s}) ; \mathrm{IR} \tilde{v}=2952(\mathrm{w}), 2869(\mathrm{w}), 1468(\mathrm{w}), 1358(\mathrm{w}), 1263(\mathrm{~s}), 1228(\mathrm{~s})$, 1171(s), 1156(s), 1121(m), 1084(s), 1061(s), 1030(s), 948(s), 917(m), 867(m), 838(s), 793(s), 770(s), 728(s), 631(s), 575(s), 515(s), 454(w), 416(w); MS (LIFDI $\left.{ }^{+}\right): m / z$ 331.136\% [1,2-disila[15]crown-5+Na] ${ }^{+}(100)$.

\section{Conclusions}

In this work, the competing coordination ability of $\mathrm{C}-, \mathrm{Si} / \mathrm{C}-$, and fully Si-bonded $\mathrm{O}$ atoms was studied. 1,2-disila[18]crown-6 as well as 1,2,4,5-tetrasila[18]crown-6 turned out to be suitable ligands, since the presence of $\mathrm{Si}_{2}$ units further increases the ring diameter in comparison to the organic crown ether [18]crown-6. Single crystals of [Li(1,2-disila[18]crown-6)] $\mathrm{PF}_{6}(\mathbf{1})$ and of $\left[\mathrm{Na}\left(1,2-\right.\right.$ disila[18] crown-6) $\left.\mathrm{PF}_{6}\right](2)$ were obtained and revealed a divergent coordination of the cation. In 1 , the highly flexible ligand completely saturates the coordination sphere of $\mathrm{Li}^{+}$, while the $\mathrm{PF}_{6}$ anion does not show any interaction with the cation. The $\mathrm{Li}^{+}$ion is preferably coordinated by the $\mathrm{Si}-$ and $\mathrm{C}$-bonded $\mathrm{O}$ atoms. Contrary to that, $\mathrm{Na}^{+}$shows stronger interaction with the $\mathrm{C}$-bonded $\mathrm{O}$ atoms of 1,2-disila[18]crown-6. Only one of the Si/C-bonded O atoms participates in the coordination. As a result, the Me groups of the Si-based part of the ligand remain in the staggered conformation, which is 
also the preferred geometry of the free ligand [18]. Contrary to Compound 1, the interaction of the $\mathrm{Si} / \mathrm{C}$-bonded $\mathrm{O}$ atoms with the cation does not compensate for the required change of conformation. The energy effort of 1,2-disila[18]crown-6 for adopting the geometry of the $\mathrm{Li}^{+}$and $\mathrm{Na}^{+}$complex was determined by DFT calculations. $\Delta E_{\text {geom }}$, in the case of 1 , has a value of $77.58 \mathrm{~kJ} \cdot \mathrm{mol}^{-1}$, which is considerably increased. In contrast, the ligand shows with $29.24 \mathrm{~kJ} \cdot \mathrm{mol}^{-1}$ smaller energy changes by coordination of $\mathrm{Na}^{+}$, which can be partially attributed to the staggered arrangement of the Si-bonded methyl groups. It follows that the electrostatic attraction between the hybrid-bonded $\mathrm{O}$ atoms and $\mathrm{Na}^{+}$ do not compensate for the required energy effort of the ecliptic arranged methyl groups. The Lewis acids therefore show a major impact on the coordinative properties of the different types of $\mathrm{O}$ atoms within hybrid crown ethers.

Similar coordination modes were also found in 1,2,4,5-tetrasila[18]crown-6 (3), which incorporates three types of $\mathrm{O}$ atoms: $\mathrm{C}-, \mathrm{Si} / \mathrm{C}-$, and Si-bonded ones. Ordinary, $\mathrm{K}^{+}$perfectly fits in [18]crown- 6 and 1,2-disila[18]crown-6 [18]. The presence of two disilane units leads to a further increase of the ligand such that 3 does not match with $\mathrm{K}^{+}$. The completely Si-bonded $\mathrm{O}$ atom, which requires the highest amount of energy to adopt the complex geometry [19], does not participate in the coordination. The complexation of the heavier homologue $\mathrm{Rb}^{+}$by 3 is an issue of current investigation. In this study, no superiority in coordination ability of each of the different types of $\mathrm{O}$ atoms was found.

The experiment on the inverse case, e.g., small ligands with large cations in 1:1 stoichiometry, leads to the dinuclear complex (5), which is bridged by four triflate anions. This crystal structure represents an initial outlook on the ability of disila-crown ethers to build sandwich complexes. Therefore, reactions in 2:1 stoichiometry of ligand to salt are crucial.

Supplementary Materials: The following are available online at www.mdpi.com/2304-6740/5/1/11/s1, Figures S1-S3: Calculated structure of 1,2-disila[18]crown-6, [Li(1,2-disila[18]crown-6)]+, [Na(1,2-disila[18]crown-6)] ${ }^{+}$; Tables S1-S3: XYZ data of 1,2-disila[18]crown-6, [Li(1,2-disila[18]crown-6)]+, [Na(1,2-disila[18]crown-6)] ${ }^{+}$.

Acknowledgments: This work was financially supported by the Deutsche Forschungsgemeinschaft (DFG).

Author Contributions: Kirsten Reuter performed the syntheses and analytics of Compounds 1-4, DFT calculations, and interpretations and wrote the paper; Fabian Dankert conducted the synthesis and characterization of Compound 5; Carsten Donsbach accomplished the measurement, crystal structure solution, and refinement of 5; Carsten von Hänisch contributed to interpretation and led the over-arching research project.

Conflicts of Interest: The authors declare no conflict of interest.

\section{References}

1. Liebau, F. Untersuchungen über die Grösse des Si-O-Si-Valenzwinkels. Acta Cryst. 1961, 14, 1103-1109. [CrossRef]

2. Almenningen, A.; Bastiansen, O.; Ewing, V.; Hedberg, K.; Trætteberg, M. The Molecular Structure of Disiloxane, $\left(\mathrm{SiH}_{3}\right)_{2} \mathrm{O}$. Acta Chem. Scand. 1963, 17, 2455-2460. [CrossRef]

3. Stone, F.G.A.; Seyferth, D. The Chemistry of Silicon Involving Probable Use of $d$-Type Orbitals. J. Inorg. Nucl. Chem. 1955, 1, 112-118. [CrossRef]

4. Craig, D.P.; Maccoll, A.; Nyholm, R.S.; Orgel, L.E. Chemical bonds involving $d$-orbitals. Part I. J. Chem. Soc. 1954, 332-353. [CrossRef]

5. Emeléus, H.J.; Onyszchuk, M. The Reaction of Methyldisoxanes and 1:1 Dimethyldisilthiane with Boron and Hydrogen Halides. J. Chem. Soc. 1958, 604-609. [CrossRef]

6. Pitt, C.G. Hyperconjugation and its Role in Group IV Chemistry. J. Organomet. Chem. 1973, 61, 49-70. [CrossRef]

7. Shambayati, S.; Schreiber, S.L.; Blake, J.F.; Wierschke, S.G.; Jorgenson, W.L. Structure and basicity of silyl ethers: A crystallographic and ab initio inquiry into the nature of silicon-oxygen interactions. J. Am. Chem. Soc. 1990, 112, 697-703. [CrossRef]

8. Cypryk, M.; Apeloig, Y. Ab Initio Study of Silyloxonium Ions. Organometallics 1997, 16, 5938-5949. [CrossRef]

9. Gillespie, R.J.; Johnson, S.A. Study of Bond Angles and Bond Lenghts in Disiloxane and Related Molecules in Terms of the Topology of the Electron Density and Its Laplacian. Inorg. Chem. 1997, 36, 3031-3039. [CrossRef] [PubMed] 
10. Grabowski, S.J.; Hesse, M.F.; Paulmann, C.; Luger, P.; Beckmann, J. How to Make the Ionic Si-O Bond More Covalent and the Si-O-Si Linkage a Better Acceptor for Hydrogen Bonding. Inorg. Chem. 2009, 48, 4384-4393. [CrossRef] [PubMed]

11. Passmore, J.; Rautiainen, J.M. On The Lower Basicity of Siloxanes Compared to Ethers. Eur. J. Inorg. Chem. 2012, 6002-6010. [CrossRef]

12. Cameron, T.S.; Decken, A.; Krossing, I.; Passmore, J.; Rautiainen, J.M.; Wang, X.; Zeng, X. Reactions of a Cyclodimethyldisiloxane $\left(\mathrm{Me}_{2} \mathrm{SiO}\right)_{6}$ with Silver Salts of Weakly Coordinating Anions; Crystal Structures of $\left.\left[\mathrm{Ag}\left(\mathrm{Me}_{2} \mathrm{SiO}\right)_{6}\right][\mathrm{Al}]\left([\mathrm{Al}]=\mathrm{FAl}\left\{\mathrm{OC}\left(\mathrm{CF}_{3}\right)_{3}\right\}_{3}\right],\left[\mathrm{Al}\left\{\mathrm{OC}\left(\mathrm{CF}_{3}\right)_{3}\right\}_{4}\right]\right)$ and Their Comparison with [Ag(18-Crown-6) $]_{2}\left[\mathrm{SbF}_{6}\right]_{2}$. Inorg. Chem. 2013, 52, 3113-3126. [CrossRef] [PubMed]

13. Decken, A.; Passmore, J.; Wang, W. Cyclic Dimethylsiloxanes as Pseudo Crown Ethers: Syntheses and Characterization of $\mathrm{Li}\left(\mathrm{Me}_{2} \mathrm{SiO}\right)_{5}\left[\mathrm{Al}\left\{\mathrm{OC}\left(\mathrm{CF}_{3}\right)_{3}\right\}_{4}\right], \mathrm{Li}\left(\mathrm{Me}_{2} \mathrm{SiO}\right)_{6}\left[\mathrm{Al}\left\{\mathrm{OC}\left(\mathrm{CF}_{3}\right)_{3}\right\}_{4}\right]$ and $\mathrm{Li}\left(\mathrm{Me}_{2} \mathrm{SiO}\right)_{6}\left[\mathrm{Al}\left\{\mathrm{OC}\left(\mathrm{CF}_{3}\right)_{2} \mathrm{Ph}\right\}_{4}\right]$. Angew. Chem. Int. Ed. 2006, 45, 2773-2777. [CrossRef] [PubMed]

14. Ritch, J.S.; Chivers, T. Silicon Analogues of Crown Ethers and Cryptands: A New Chapter in Host-Guest Chemistry? Angew. Chem. Int. Ed. 2007, 46, 4610-4613. [CrossRef] [PubMed]

15. Von Hänisch, C.; Hampe, O.; Weigend, F.; Stahl, S. Stepwise Synthesis and Coordination Compound of an Inorganic Cryptand. Angew. Chem. Int. Ed. 2007, 46, 4775-4779. [CrossRef] [PubMed]

16. Inoue, Y.; Ouchi, M.; Hakushi, T. Molecular Design of Crown Ethers. 3. Extraction of Alkaline Earth and Heavy Metal Picrates with 14- to 17-Crown-5 and 17- to 22-Crown-6. Bull. Chem. Soc. Jpn. 1985, 58, 525-530. [CrossRef]

17. Ouchi, M.; Inoue, Y.; Kanzaki, T.; Hakushi, T. Ring-contracted Crown Ethers: 14-Crown-5, 17-Crown-6, and Their Sila-analogues. Drastic Decrease in Cation-binding Ability. Bull. Chem. Soc. Jpn. 1984, 57, 887-888. [CrossRef]

18. Reuter, K.; Buchner, M.R.; Thiele, G.; von Hänisch, C. Stable Alkali-Metal Complexes of Hybrid Disila-Crown Ethers. Inorg. Chem. 2016, 55, 4441-4447. [CrossRef] [PubMed]

19. Reuter, K.; Thiele, G.; Hafner, T.; Uhlig, F.; von Hänisch, C. Synthesis and coordination ability of a partially silicon based crown ether. Chem. Commun. 2016, 52, 13265-13268. [CrossRef] [PubMed]

20. Dalley, N.K.; Lamb, J.D.; Nazarenko, A.Y. Crystal Structure of the Complex of 1,4,7,10,13,16-Hexacyclooctadecane with Lithium Picrate Dihydrate. Supramol. Chem. 1997, 8, 345-350.

21. Chadwick, S.; Ruhlandt-Senge, K. The Remarkable Structural Diversity of Alkali Metal Pyridine-2-thiolates with Mismatched Crown Ethers. Chem. Eur. J. 1998, 4, 1768-1780. [CrossRef]

22. Akutagawa, T.; Hasegawa, T.; Nakamura, T.; Takeda, S.; Inabe, T.; Sugiura, K.; Sakata, Y.; Underhill, A.E. Ionic Channel Structures in $\left[\left(\mathrm{M}^{+}\right)_{x}([18] \text { crown-6)][Ni(dmit })_{2}\right]_{2}$ Molecular Conductors. Chem. Eur. J. 2001, 7 , 4902-4912. [CrossRef]

23. Dankert, F.; Reuter, K.; Donsbach, C.; von Hänisch, C. A Structural Study of Alkaline Earth Metal Complexes with Hybrid Disila-Crown Ethers. Dalton Trans. 2017. [CrossRef] [PubMed]

24. Olsher, U.; Izatt, R.M.; Bradshaw, J.S.; Dalley, N.K. Coordination chemistry of lithium ion: A crystal and molecular structure review. Chem. Rev. 1991, 91, 137-164. [CrossRef]

25. Gingl, F.; Hiller, W.; Strähle, J. [Li(12-Krone-4)]Cl: Kristallstruktur und IR-Spektrum. Z. Anorg. Allg. Chem. 1991, 606, 91-96. [CrossRef]

26. Liddle, S.T.; Clegg, W. A homologous series of crown-ether-complexed alkali metal amides as discrete ion-pair species: Synthesis and structures of $\left[M(12 \text {-crown-4) })_{2}\right][\mathrm{PyNPh} \cdot \mathrm{PyN}(\mathrm{H}) \mathrm{Ph}](\mathrm{M}=\mathrm{Li}, \mathrm{Na}$ and $\mathrm{K})$. Polyhedron 2003, 22, 3507-3513. [CrossRef]

27. Feldmann, C.; Okrut, A. Two Tricyclic Polychalcogenides in [Li(12-crown-4 $\left.)_{2}\right]_{2}\left[\mathrm{Sb}_{2} \mathrm{Se}_{12}\right]$ and [Li(12-crown-4) $\left.]_{4}\right]_{4}\left[\mathrm{Te}_{12}\right] \cdot(12$-crown-4) 2 . Z. Anorg. Allg. Chem. 2009, 635, 1807-1811. [CrossRef]

28. Turbomole, version 7.0; Turbomole Is a Development of University of Karlsruhe and Forschungszentrum Karlsruhe 1989-2007, Turbomole GmbH 2016. Turbomole GmbH: Karlsruhe, Germany, 2007.

29. Weigend, F.; Ahlrichs, R. Balanced bass sets of split valence, triple zeta valence and quadruple zeta valence quality for H to Rn: Design and assessment of accuracy. Phys. Chem. Chem. Phys. 2005, 7, 3297-3305. [CrossRef] [PubMed]

30. Weigend, F. Accurate Coulomb-fitting basis sers for H to Rn. Phys. Chem. Chem. Phys. 2006, 8, 1057-1065. [CrossRef] [PubMed]

31. Dolg, M.; Stoll, H.; Savin, A.; Preuss, H. Energy-adjusted pseudopotentials for the rare earth elements. Theoret. Chim. Acta 1989, 75, 173-194. [CrossRef] 
32. Stoll, H.; Metz, B.; Dolg, M. Relativistic energy-consistent pseudopotentials-Recent developments. J. Comput. Chem. 2002, 23, 767-778. [CrossRef] [PubMed]

33. Grimme, S.; Antony, J.; Ehrlich, S.; Krieg, H. A consistent and accurate ab initio parametrization of density functional dispersion correction (DFT-D) for the 94 elements H-Pu. J. Chem. Phys. 2010, 132, 154104-154119. [CrossRef] [PubMed]

34. Grimme, S.; Ehrlich, S.; Goerigk, L. Effect of the damping function in dispersion corrected density functional theory. J. Comput. Chem. 2011, 32, 1456-1465. [CrossRef] [PubMed]

35. Willcott, M.R. MestRe Nova. J. Am. Chem. Soc. 2009, 131, 13180. [CrossRef]

36. Klamt, A.; Schüürmann, G. COSMO: A new approach to dielectric screening in solvents with explicit expressions for the screening energy and its gradient. J. Chem. Soc. Perkin. Trans. 1993, 2, 799-805. [CrossRef]

37. Sheldrick, G.M. SHELXL14; Program for the Refinement of Crystal Structures; Universität Göttingen: Göttingen, Germany, 2014.

38. Dolomanov, O.V.; Bourhis, L.J.; Hildea, R.J.; Howard, J.A.K.; Puschmann, H. Olex2: A complete structure solution, refinement and analysis program. J. Appl. Crystallogr. 2009, 42, 339-341. [CrossRef]

39. Putz, H.; Brandenburg, K. Diamond-Crystal and Molecular Structure Visualization; Crystal Impact: Bonn, Germany, 2012.

(C) 2017 by the authors; licensee MDPI, Basel, Switzerland. This article is an open access article distributed under the terms and conditions of the Creative Commons Attribution (CC BY) license (http:/ / creativecommons.org/licenses/by/4.0/). 